\title{
Dry season drinking from terrestrial man-made watering holes in arboreal wild Temminck's red colobus, The Gambia
}

\author{
A. P. Hillyer ${ }^{1}$, R. Armstrong ${ }^{2}$, and A. H. Korstjens ${ }^{1}$ \\ ${ }^{1}$ Faculty of Science and Technology, Bournemouth University, Dorset, UK \\ ${ }^{2}$ Centre for Wildlife Conservation, University of Cumbria, Cumbria, UK \\ Correspondence to: A. P. Hillyer (alisonhillyer@yahoo.co.uk)
}

Received: 21 December 2014 - Revised: 11 May 2015 - Accepted: 12 May 2015 - Published: 12 June 2015

\begin{abstract}
Like most arboreal primates, red colobus monkeys obtain most water from plants in their diet, licking their body or drinking occasionally from standing water in tree holes. Terrestrial drinking is not normally reported for arboreal primates. Here we report observations of terrestrial drinking from man-made watering holes by Temminck's red colobus (Piliocolobus badius temminckii) in Abuko Nature Reserve and Bijilo Forest Park, The Gambia. Colobus drinking behaviour in Abuko has been reported previously by Starin (1991, 2002), mostly involving juveniles or lactating females; water was most commonly obtained by licking water from the body and leaves or obtained from tree holes. Some juveniles were seen drinking from swampy ground and puddles in the dry season, but otherwise the only terrestrial water body available to colobus during the study by Starin contained crocodiles, a known predator of red colobus at the site. Our observations show that shallow man-made watering holes that have since been created and do not harbour predators were used by different age classes. We discuss some of the implications of this behaviour for this endangered subspecies and report on the trend of increasing temperatures in The Gambia.
\end{abstract}

\section{Introduction}

Observations of primate drinking behaviour are not regularly reported, but terrestrial drinking events by arboreal primates do represent an interesting behaviour considering the risk of predation and increased parasite-disease risk associated with terrestriality, especially standing water. Arboreality can help to evade soil-transmitted endoparasitism (Loudon and Sauther, 2013). Parr et al. (2013) reported that white-faced capuchins (Cebus capucinus) were more likely to be infected with Strongyloides sp. during the dry season when the monkeys descend to the forest floor to drink. Terrestrial drinking in most arboreal primate species is not reported; however, there are notable examples: mantled howler monkeys (Alouatta palliata) came to the ground to drink from standing water in Costa Rica during exceptionally dry conditions (Gilbert and Stouffer, 1989), and Geoffroy's spider monkeys (Ateles geoffroyi) in Costa Rica are known to drink from water holes (Chapman, 1988).
Here we report preliminary observations of an arboreal primate, Temminck's red colobus (Piliocolobus badius temminckii), drinking from man-made terrestrial water holes during the dry season in Abuko Nature Reserve and Bijilo Forest Park, The Gambia. Prior to this study Temminck's colobuses were recorded to drink occasionally in Abuko Reserve (Starin, 1991, 2002); drinking was reported mostly in lactating females and juveniles and to occur more in the wet (4/12 months: June-October) compared with the dry season (8/12 months: October-June) during a 5-year study from 1978 to 1983 and a further 6-month study in 1996. It is not known whether sampling effort was equally distributed in the dry and wet seasons. Starin followed a focal group, which had a natural water pool ( $0.8 \%$ of the reserve area) within their territory, but it was (and still is) inhabited by crocodiles, a known predator of the colobus. The group were never seen to drink from the pool, but juveniles were seen drinking from swampy ground and puddles $(5 \times 7 \mathrm{~cm})$ in the dry season. 
Terrestrial drinking could be influenced by various factors such as absence of predation pressure, group competition influencing spatial-temporal use of home range, climate and habitat-dietary change related to water requirement. In this paper we report drinking events from two different populations of $P$. b. temminckii collected either via direct observation or camera trapping and will discuss the data together with climate-temperature data (since 1970).

\section{Methods}

\subsection{Study sites and species}

Data were collected on Temminck's colobus groups in two isolated populations: Abuko Nature Reserve (ANR) $\left(13^{\circ} 23^{\prime} 45^{\prime \prime} \mathrm{N}, 16^{\circ} 38^{\prime} 44^{\prime \prime} \mathrm{W}\right)$ and Bijilo Forest Park (BFP) $\left(13^{\circ} 25^{\prime} 58^{\prime \prime} \mathrm{N}, 16^{\circ} 43^{\prime} 35^{\prime \prime} \mathrm{W}\right)$, The Gambia. Both ANR and BFP are protected reserves and listed as two of the most important sites for the subspecies (Butynski et al., 2013). Permits were obtained from the Forestry Department to work in BFP and the Department of Parks and Wildlife Management in ANR. $P$. b. temminckii is an endangered subspecies of the western red colobus ( $P$. badius); endemic to West Africa, it is found in southern Senegal, The Gambia, Guinea-Bissau, NW Guinea and Sierra Leone. The subspecies' range is considerably fragmented: the northern boundary has retreated, and many populations exist in isolation (Galat et al., 2009).

ANR is 106.6 ha in area, composed of gallery forest $(16 \%)$, tree and shrub $(56.6 \%)$, savannah and woodland savannah $(24.8 \%)$, crocodile-inhabited freshwater pool $(0.8 \%)$ and swamp (0.3\%) (Starin, 1991). The freshwater pool and swamp is located in the home range of two colobus groups (most likely to be the area used by Starin's focal group). Apart from the freshwater pool and swamp there is a manmade pool, situated in front of a hide in the home range of one group, here named "orphanage group" (not the focal group during Starin's study). The pool is approximately $2 \mathrm{~m}^{2}$ and $20 \mathrm{~cm}$ deep (if filled to maximum). The pool was created in 1996 approximately and filled on an ad hoc basis. Green monkeys (Chlorocebus aethiops sabaeus) frequented the pool to drink. Known predators in the reserve include West African crocodiles (Crocodylus suchus) and snakes of different species (Starin, 1991). There is an additional threat from domestic dogs entering the reserve; ANR is surrounded by towns and agricultural land. The study was carried out between March and June 2013 (dry season).

BFP is 51.3 ha in area and comprises a combination of sand dunes, savannah and rhun palm forest. Possible predators here include snakes and feral dogs. As in ANR two primate species inhabit this park: green monkeys and Temminck's colobus. The colobuses in BFP do not flee from tourists and as such can be regarded as semi-habituated. The forest has no permanent, natural sources of drinking water; however, in 2009 two concrete-lined "water holes" were created. Both pools are around $2 \mathrm{~m} \times 3 \mathrm{~m}$ and are filled on an

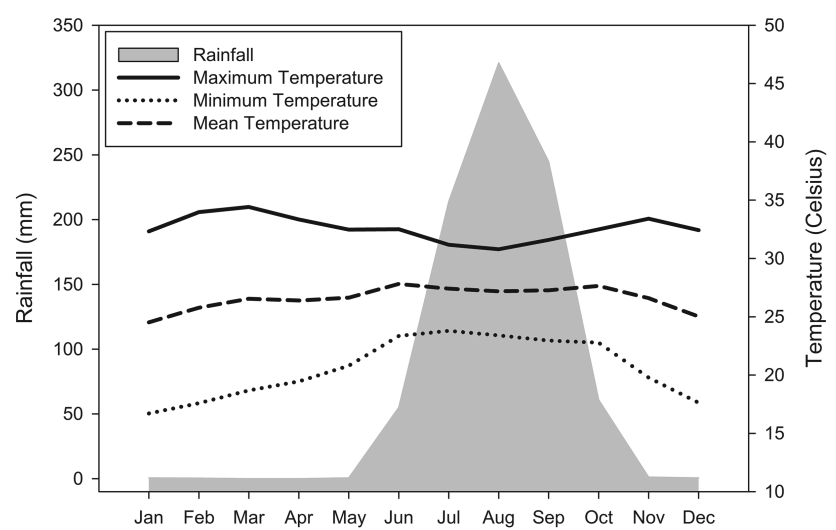

Figure 1. Average rainfall $(\mathrm{mm})$ and maximum, mean and minimum temperatures (degrees Celsius) per month of the year (from 1970 until 2011).

ad hoc basis resulting in water depths of $0-20 \mathrm{~cm}$. The data were collected in April 2013 in BFP.

\subsection{Behavioural sampling}

Behavioural studies were carried out in ANR but not BFP. Dawn to dusk group follows were carried out on 42 days (504 h). Most of the colobuses were very shy and ran from people and as such could be considered unhabituated. One group near the reserve entrance, named "entrance group" (most likely the same area used by the focal group in Starin's study) could be considered semi-habituated as they differed in their reaction to visitors. Five groups (of an estimated seven groups) were followed; two groups were observed to have a natural water pool within their range and another group, "orphanage group", a man-made water hole within its home range.

\subsection{Trail camera data}

In both ANR and BFP trail cameras were used to monitor activity at water holes. In ANR, Bushnell "Trophy Camera" model 119437 was used for 4 consecutive days, $24 \mathrm{~h}$ a day, placed at approximately 1-2 $\mathrm{m}$ height off the ground with a view of the whole pool. The Bushnell trail camera model is triggered by movement. The data from BFP were collected with the same camera model, positioned at $1-2 \mathrm{~m}$ height in a position where $>90 \%$ of the water hole could be monitored, for 10 days, $24 \mathrm{~h}$ a day. Typical human disturbance at the water holes was 1-2 visits per day.

\subsection{Climate data}

Temperature and precipitation data were obtained from Yundum Meteorological Station, $1.25 \mathrm{~km}$ from ANR. Mean annual temperature $\left({ }^{\circ} \mathrm{C}\right)$ and mean annual precipitation $(\mathrm{mm})$ data were analysed using linear regression analysis in SPSS 
Table 1. A summary of all drinking events observed (ANR being Abuko Nature Reserve and BFP being Bijilo Forest Park).

\begin{tabular}{|c|c|c|c|c|}
\hline Site & Date and time & Duration (minutes) & $\begin{array}{l}\text { No. of } \\
\text { individuals }\end{array}$ & Age and sex \\
\hline ANR & $\begin{array}{l}16 \text { Apr } 2013 \\
\text { 5:06 p.m. }\end{array}$ & $\begin{array}{l}\text { Unknown (encountered by } \\
\text { chance and interrupted) }\end{array}$ & 5 & $\begin{array}{l}3 \text { adults (sex unknown) and } \\
2 \text { juveniles }\end{array}$ \\
\hline ANR & $\begin{array}{l}18 \text { Apr } 2013 \\
\text { approx. 5:00 p.m. }\end{array}$ & $\begin{array}{l}\text { Unknown (encountered by } \\
\text { chance and interrupted) }\end{array}$ & 10 & Not recorded \\
\hline ANR & $\begin{array}{l}5 \text { May } 2013 \\
\text { 3:49 p.m. }\end{array}$ & 7 & 2 & Adult female with infant \\
\hline BFP & $\begin{array}{l}18 \text { Apr } 2013 \\
12: 58 \text { a.m. }\end{array}$ & 36 & $10+$ & $\begin{array}{l}\text { Mostly adult females with in- } \\
\text { fants and a few immature in- } \\
\text { dividuals }\end{array}$ \\
\hline BFP & $\begin{array}{l}21 \text { Apr } 2013 \\
\text { 2:30 p.m. }\end{array}$ & 18 & $10+$ & $\begin{array}{l}\text { Mostly females with infants } \\
\text { and immature individuals, } \\
\text { briefly joined by adult male } \\
\text { and what appeared to be } 2 \\
\text { immature males; the imma- } \\
\text { ture males drank but the adult } \\
\text { male did not. }\end{array}$ \\
\hline BFP & $\begin{array}{l}\text { 21 Apr } 2013 \\
\text { 3:40 p.m. }\end{array}$ & 0.5 & 1 & A subadult \\
\hline BFP & $\begin{array}{l}24 \text { Apr } 2013 \\
\text { 9:45 a.m. }\end{array}$ & 0.5 & 3 & $\begin{array}{l}\text { Adult female with infant and } \\
\text { another adult female }\end{array}$ \\
\hline BFP & $\begin{array}{l}24 \text { Apr } 2013 \\
\text { 11:07 a.m. }\end{array}$ & 10 & 8 & $\begin{array}{l}5 \text { adult females and } 2 \text { infants } \\
\text { and a juvenile }\end{array}$ \\
\hline
\end{tabular}

10.0. The dry season is October-June (Starin, 1991); see absence of rainfall in Fig. 1.

\section{Results}

\subsection{Drinking observations and trail camera data, Abuko Nature Reserve}

Eight drinking events were observed. Two of the events were seen during dawn to dusk group follows in ANR; the other events were recorded using trail cameras. Table 1 summarises all drinking events. On 16 April 2013, while following the orphanage group, at 5:06 p.m. LT, 3 adults and 2 juveniles of unknown sex were seen drinking from the man-made pool in their home range. Other juveniles were by the pool, but the group fled when A. P. Hillyer was noticed. On 18 April 2013 in the late afternoon 10 individuals of unknown age and sex were seen drinking at the pool by a field assistant. The "orphanage" group had been seen drinking from the pool on various occasions by the field assistant before the start of this study. The trail camera further recorded an adult female with an infant at the pool from 3:49 to 3:55 p.m., on 5 May 2013. The female squatted to drink but the infant was not captured drinking (Fig. 2 in the Supplement).
Other orphanage group individuals were seen on various occasions around the pool in mixed age groups but not drinking. In some cases a potential drinking event may have been interrupted as a response to the observer.

\subsection{Trail camera data, Bijilo Forest Park}

During the data collection period, the water hole was visited on five occasions by groups varying in size from a single individual to over 10 individuals (Fig. 3 in the Supplement). Adult females drank from the pool (whether adult males drank could not be determined), as did immature individuals; R. Armstrong categorised groups of juveniles and subadults as one class: immature individuals. Attendance time at the pools ranged from 0.5 to $36 \mathrm{~min}$. The longest visits were also the occasions on which most individuals were present $(>10)$, whereas the shortest visit involved only a single individual. Colobuses did not just visit the pools to drink; instead they stayed in the vicinity for some time and engaged in social behaviour with conspecifics (including play-chases and soliciting copulation) and green monkeys (play-chases). On 24 April 2013 a group of three colobuses (Table 1) were encountered drinking at the water hole ad libitum at 9:45 a.m. 


\subsection{Climate data}

Mean, minimum and maximum annual temperatures all increased significantly between 1970 and 2011 (linear regression: $\mathrm{df}=1$ and 40: mean temperature $R^{2}=0.607$, $p<0.001 ; T_{\min }: R^{2}=0.682, p<0.001 ; T_{\max }: R^{2}=0.426$, $p<0.001)$. In contrast, mean annual precipitation did not change significantly between 1970 and $2011\left(R^{2}=0.48\right.$, $P=0.162$ ). Rainfall and temperature variation (measured as standard deviation between months over the year) did not change significantly (rainfall: $R_{1,40}^{2}=0.044, p=0.185$; temperature: $\left.R_{1,40}^{2}=0.041, p=0.199\right)$. Temperature and precipitation values can be seen in Fig. 4 (Supplement).

\section{Discussion}

The observations presented here suggest $P$. b. temminckii will use a ground pool if available and safe. There are no crocodiles near the man-made water holes at both sites during the day (they are known to travel in ANR at night) (I. Jarjou, personal communication, 2013). With reference to ANR, prior drinking observations reported for Temminckii's red colobus (Starin, 2002) involved monkeys mostly licking water from leaves, tree bowls or their own bodies. The only incidences of a terrestrial nature occurred in the dry season, which involved juveniles sometimes drinking from swampy ground (number of events unknown) and juvenile/immature individuals drinking on four occasions from puddles. Contrary to our observations, Starin reported that adults did not actively seek water nor did the colobus use a water hole. However, there was no water hole available as a safe drinking resource for the focal group during her studies. Furthermore, Starin observed a different group to that which A. P. Hillyer observed drinking. As well as the limited duration of our study this means a comparison cannot be made. Unfortunately, there are no prior records of drinking behaviour in BFP.

Provisioning in the form of terrestrial, man-made water holes could pose risks to the colobus such as increased exposure to disease or predation. They are least careful when at ground level (Starin, 1991). Of particular concern here are (1) the presence of domestic dogs in both ANR (Starin, 1991; A. P. Hillyer, personal observation, 2013) and BFP (R. Armstrong, personal observation, 2013), which are known to hunt colobus (Galat-Luong and Galat, 2005), and (2) in ANR livestock carcasses (used to feed captive hyenas within the home range of the orphanage group) were left in contact with the ground, on which the colobus frequently cross. This has implications for colobus health/survival. An increasing temperature trend was found for the period 1970-2011, but whether this has or will influence terrestrial drinking in colobus cannot be determined with the present data. As mentioned before, ANR and BFP are listed as two important sites for Temminck's colobus; the threats discussed here warrant further long-term investigation.

\section{The Supplement related to this article is available online at doi:10.5194/pb-2-21-2015-supplement.}

Author contributions. A. P. Hillyer and R. Armstrong observed the events in the field. A. P. Hillyer prepared the manuscript with contributions from R. Armstrong and A. H. Korstjens. A. P. Hillyer and A. H. Korstjens carried out statistical analyses.

Acknowledgements. The authors are grateful to the Department of Parks and Wildlife Management and the Forestry Department, The Gambia, for allowing the research at the two sites. A. P. Hillyer would like to thank Ibou Jarjou for his valuable knowledge of the colobus in ANR and his assistance in the field. R. Armstrong would like to thank Sulayman Jobe for his continued support and assistance in BFP. Thank you to Mr Saikou Kolley, Yundum Meteorological Station. We also appreciate the suggestions from Jan Gogarten and an anonymous reviewer, which improved the manuscript.

Edited by: J. Ostner

Reviewed by: J. Gogarten and one anonymous referee

\section{References}

Butynski, T. M., Grubb, P., and Kingdon, J.: Procolobus badius (Western red colobus), in: The Mammals of Africa, edited by: Butynski, T. M., Kingdon, J., and Kalina, J., Vol. 2, Bloomsbury publishing, London, UK, 128-134, 2013.

Chapman, C.: Patterns of foraging and range use by three species of neotropical primates, Primates, 29, 177-194, 1988.

Galat, G., Galat-Luong, A., and Nizinski, G.: Increasing dryness and regression of the geographical range of Temminck's red colobus Procolobus badius temminckii: implications for its conservation, Mammalia, 73, 365-368, 2009.

Galat-Luong, A. and Galat, G.: Conservation and survival adaptations of Temminck's red colobus (Procolobus badius temmincki), in Senegal, Int. J. Primatol., 26, 585-603, 2005.

Gilbert, K. A. and Stouffer, P. C.: Use of a ground water source by mantled howler monkeys (Alouatta palliata), Biotropica, 21, p. 380, 1989.

Loudon, J. E. and Sauther, M. L.: Verreaux's sifaka (Propithecus verreauxi) and ring-tailed lemur (Lemur catta) endoparasitism at the Bezà Mahafaly Special Reserve, Madagascar Cons and Dev., 8, 21-28, 2013.

Parr, N. A., Fedigan, L. M., and Kutz, S. J.: Predictors of parasitism in wild white-faced capuchins (Cebus capucinus), Int. J. Primatol., 34, 1137-1152, 2013.

Starin, E. D.: Socioecology of the red colobus monkey in the Gambia with particular reference to female-male differences and transfer patterns, PhD thesis: City University of New York, New York, 406 pp., 1991.

Starin, E. D.: Drinking observations in Temminck's red colobus, Folia Primatol., 73, 137-139, 2002. 